\title{
SISTEM INFORMASI PENGABDIAN MASYARAKAT RUTIN POLITEKNIK NEGERI KUPANG
}

\author{
Folkes Laumal ${ }^{1}$, Nirmala Resi ${ }^{2}$
}

\begin{abstract}
Abstrak :
Pengusulan Program Penelitian dan Pengabdian kepada Masyarakat tahun 2016 ini merupakan pelengkap penjelasan secara teknis bagi peneliti dan pelaksana pengabdian dalam mengusulkan skema hibah secara daring melalui Simlitabmas dengan mengacu pada Panduan Pelaksanaan Penelitian dan Pengabdian kepada Masyarakat di Perguruan Tinggi Edisi X Tahun 2016. Diterbitkannya panduan ini dimaksudkan agar lembaga pengusul, peneliti, atau pelaksana kegiatan pengabdian kepada masyarakat akan dapat memahami mekanisme, dan prasyarat yang harus dipenuhi ketika akan membuat dan mengusulkan proposal melalui Simlitabmas. Kegiatan pengusulan pendanaan penelitian dan pengabdian melalui Simlitabmas merupakan implementasi dari kebijakan Kemenristek dikti dalam mekanisme pengelolaan riset dan pengabdian kepada masyarakat di perguruan tinggi dibawah koordinasi oleh Direktorat Jenderal Penguatan Riset dan Pengembangan. Pengajuan pengusulan untuk seluruh skema dilakukan secara daring melalui Simlitabmas melalui http://simlitabmas.ristekdikti.go.id. Pengusul harus mengikuti ketentuan umum sebagai pedoman standar penjaminan mutu penelitian dan pengabdian kepada masyarakat di perguruan tinggi sesuai dengan rambu-rambu yang telah ditetapkan dalam Panduan Penelitian dan Pengabdian kepada Masyarakat Edisi X Tahun 2016. Berkenaan dengan hal tersebut, DRPM menetapkan ketentuan umum pelaksanaan program penelitian dan pengabdian kepada masyarakat
\end{abstract}

Kata Kunci : Panduan Pengusulan Program Penelitiandan Pengabdian Kepada Masyarakat Melalui Simlitabmas.

\section{PENDAHULUAN}

Politeknik Negeri Kupang adalah salah satu perguruan tinggi yang ada di kota Kupang. Politeknik Negeri Kupang sebagai perguruan tinggi juga menggunakan wahana Tridharma perguruan tinggi yaitu pendidikan, penelitian, dan pengabdian masyarakat rutin. Dimana pengabdian masyarakat bertujuan meyakinkan hubungan antara Politeknik Negeri Kupang dengan masyarakat melalui kerjasama yang selektif. Karena itu pengabdian merupakan wahana proses belajar bagi dosen dan mahasiswa.

Selama ini proses pengelolahan pengabdian masyarakat di Politeknik Negeri Kupang dita- ngani oleh Unit Penelitian dan Pengabdian Masyarakat (UPPM) yang berada dibawah Direktur Politeknik Negeri Kupang. Unit ini mengelola seluruh usulan proposal pengabdian dari dosen baik pengabdian Nasional maupun pengabdian yang bersumber dari dana DIPA Politeknik Negeri Kupang.

Untuk pengabdian nasional proses pengolahan data sudah dilakukan secara online melalui Simblitabmas.ristekdikti.go.id dengan sistem tersebut persoalan-persoalan mengenai pengolahan data evaluasi dan pengumuman sudah dilakukan secara online, Sedangkan khusus pengabdian yang bersumber dari dana DIPA Politeknik Negeri Kupang, proses pengusulan 
proposal, evaluasi, dan pengumuman masih dilakukan dengan cara konvensional dimana dosen menulis proposal, membukukan, dan memasukan (mengumpulkan) ke bagian administrasi UPPM, kemudian menginput data pada lembaran buku dan juga dalam komputer menggunakan aplikasi EXCEL.

Cara ini memberikan banyak persoalan diantaranya ada keterlamabatan dosen dalam mengumpulkan proposal dengan berbagai alasan, sehingga proses penilaian dianggap tidak adil, kemudian jangka waktu yang ditentukan unit terkadang berubah karena keterlambatan dosen dalam pengumpulan proposal dan penilaian dosen tentang pengelolaan data yang tidak merata.

Dengan kondisi-kondisi ini maka penulis ingin membuat "Sistem Informasi Pengabdian Masyarakat Rutin Di UPPM Politeknik Negeri Kupang" yang terintegrasi dengan website Politeknik Negeri Kupang dan diharapkan dapat membantu petugas penerima proposal pengabdian masyarakat rutin Politeknik Negeri Kupang dalam pekerjaannya serta dapat membantu memudahkan dosen dan mahasiswa dalam mendapat segala informasi tentang unit penelitian dan pengabdian masyarakat Politeknik Negeri Kupang.

\section{TINJAUAN PUSTAKA}

Penelitian yang dilakukan oleh Nugroho (2012) tentang perkembangan system informasi manajemen proyek berbasis web. Dari hasil perancangan sistem informasi manajemen proyek berbasis website, dapat diambil kesimpulan sebagai berikut: Dalam sistem informasi ini telah dibangun sebuah database server proyek yang menggunakan MySQL yang telah mendukung RDBMS, yang semua data yang diolah menjadi laporan proyek berasal dari 1 (satu) sumber dan di simpan dalam server tersebut sehingga memudahkan dalam penyimpanan dan pencarian.

Penelitian yang dilakukan oleh Hamzah (2016) membuat sistem informasi sistem pengolahan data kegiatan penelitian dan pengabdian kepada masyarakat di Universitas Respati
Yogyakarta, sistem informasi tersebut dilakukan untuk melakukan proses pengolahan penelitian dan pengabdian kepada masyarakat yang dikelola oleh Unit penelitian dan pengabdian pada masyarakat Universitas Yogyakarta. Pengolahan mengacu pada komponen beban kerja dosen dibidang penelitian dan pengabdian pada masyarakat dalam proses pengolahan data rekam jejak kegiatan pengabdian kepada masyarakat yang dilakukan dosen.

Penelitian yang dilakukan oleh Indrajani (2017) melakukan analisis dan perancangan sistem penjualan berbasis web pada PT. Sarang Imitasi merupakan sebuah perusahaan yang bergerak dibidang supplier aksesoris minuman terutama untuk produk snack, stationery (alatalat tulis, tas sekolah, dan sebagainya), produk elektronik (jam tangan, radio mini, dan sebagainya) dan imitasi dilakukan dengan tujuan merancang sistem penjualan dan transaksi secara online. Dengan sistem yang ada transaksi pembelian dan penukaran informasi barang (data, gambar produk dan harga) dengan konsumen dapat berjalan dengan mudah.

Sistem itu berasal dari bahasa Yunani yang artinya kesatuan. Suatu sistem terdiri dari elemen-elemen yang saling berinteraksi untuk mencapai tujuan tertentu. "Sistem adalah suatu jaringan kerja yang terdiri dari prosedurprosedur yang saling berhubungan, berkumpul bersama-sama untuk melakukan suatu kegiatan atau menyelesaikan suatu sasaran tertentu" Sigit, (1999). Suatu sistem dalam mencapai tujuannya tentu memerlukan suatu proses yang terdiri atas bermacam-macam tipe proses misalnya proses secara konsep, proses secara fisik, proses secara prosedur, proses secara sosial dan lain-lainnya.

Kristanto (2003), mendefinisikan sistem adalah jaringan kerja dari prosedur-prosedur yang saling berhubungan, berkumpul bersamasama untuk melakukan suatu kegiatan atau menyelesaikan suatu sasaran tertentu. Suatu sistem yang baik harus mempunyai tujuan dan sasaran yang tepat karena hal ini akan sangat menentukan dalam mendefinisikan masukan 
yang dibutuhkan sistem dan juga keluaran yang dihasilkan.

Informasi adalah data yang telah diolah menjadi bentuk yang lebih berguna dan lebih berarti bagi yang menerimanya. Sumber informasi adalah data, data adalah bentuk jamak dari bentuk tunggal datum atau data item. Data adalah kenyataan yang menggambarkan suatu kejadian-kejadian dan kesatuan nyata. Kejadiankejadian (event) adalah sesuatu yang terjadi pada saat tertentu. Budiarti (1999), mendefinisikan informasi adalah data yang telah diolah menjadi sebuah bentuk yang berarti bagi penerimanya dan bermanfaat dalam mengambil keputusan saat ini atau mendatang.

Supriyanto (2005) informasi adalah data yang telah diolah menjadi bentuk yang lebih berarti bagi penerimanya dan bermanfaat dalam mengambil keputusan saat ini atau mendatang.

\section{METODE PENELITIAN}

\section{Metode Pengumpulan Data}

a. Observasi, dilakukan dengan mengadakan penelitian langsung dengan instansi terkait untuk mengumpulkan informasi dan data yang dibutuhkan dalam menunjang permasalahan.

b.Studi Pustaka, dilakukan dengan membaca dan mempelajari buku-buku yang terkait dengan masalah, serta mencari dan mempelajari dari media internet.

c. Wawancara, dilakukan dengan bertanya langsung dengan orang yang terkait dengan dalam instansi mengenai kebutuhan sesuai permasalahan.

d.Model Perancangan Sistem

Metode yang digunakan dalam pembuatan Sistem Informasi Pengabdian Masyarakat Rutin Politeknik Negeri Kupang adalah metode Waterfall, yang terdiri dari :
Analisa Kebutuhan

a. Alat

1.Laptop, Layar 14inch BrightView LEDbacklit Display Resolusi : 1366x768 processor: $1.6 \mathrm{GHz}$, Ukuran Hard Drive: 320 GB SATA, RPM:5400rpm, Ukuran Memory: 2GB Supports up to $8 G B$, Tipe Memory:DDR3

2.Sistem Informasi, Windows 7 Pro (64bnit)

3.Bahasa Pemrograman, HTML, PHP, Javascript, css

4.Web Browser, Mozila Firefox v45.1.2.Google Crome v35.1.1500.89

5.Web Server, XAMPP Apache Server 1.7.3

6.Database Server, MySQL GUI 5.1.41

7.Editor, Notepad $++v 6.5 .1$

8.Image Editor, Adobe Photoshop CS5

b. Kebutuhan Input

Adapun kebutuhan input dari Sistem Informasi Pengabdian Masyarakat Rutin Politeknik Negeri Kupang antara lain :

Dalam sistem ini dibutuhkan juga kebutuhan input sehingga dapat menginput data. Data yang di input yaitu: Data Dosen, Data Anggota dan Data Pengabdian.

c. Kebutuhan output dari Sistem Informasi Pengabdian Masyarakat Rutin Politeknik Negeri Kupang antara lain :

1.Laporan Pengabdian

2.Laporan Reviewer

Bagian Alur Sistem Sistem

a. Flow Chart SI Pengabdian Masyarakat Rutin PNK 


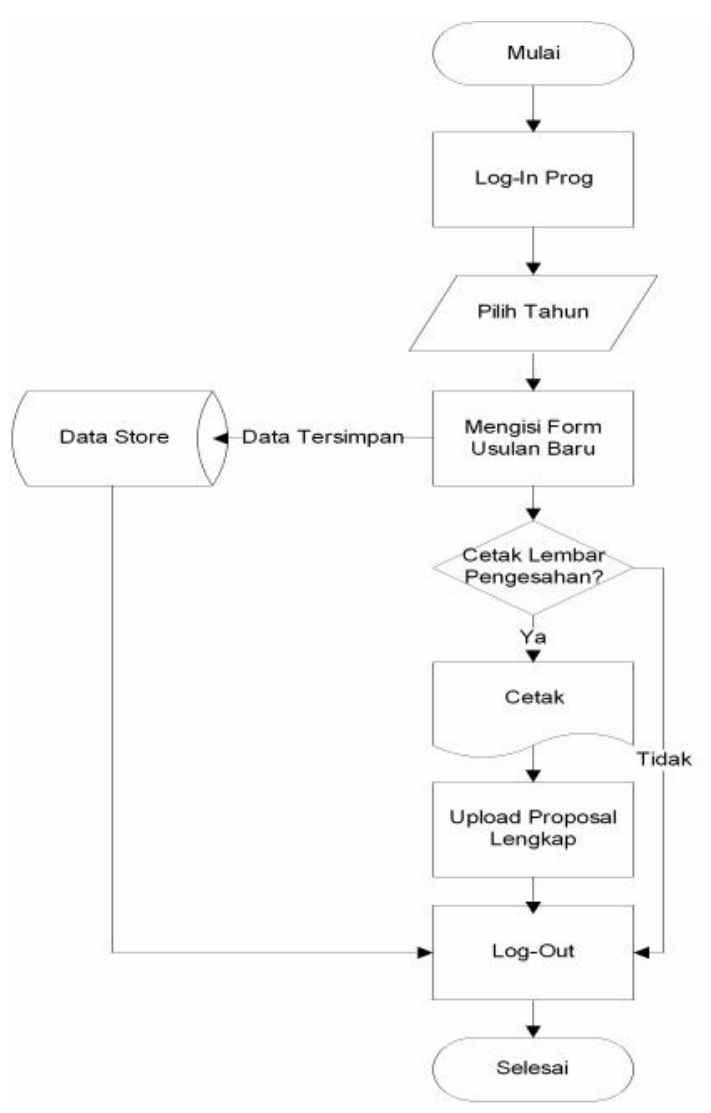

Pada Gambar 1 diatas Dosen masuk ke pengabdian kemudian user memilih tahun pengabdian, setelah itu dosen mengisi form usulan baru kemudian dosen mencetak lembar pengesahan, jika tidak ingin mencetak lembar pengesahan maka dosen keluar dari sistem, jika dosen memilih cetak lembar pengesahan maka selanjutnya dosen mengupload proposal pengabdian lengkap, setelah itu dosen keluar dari sistem.
b.Flow Chart Pelaksanaan Kegiatan

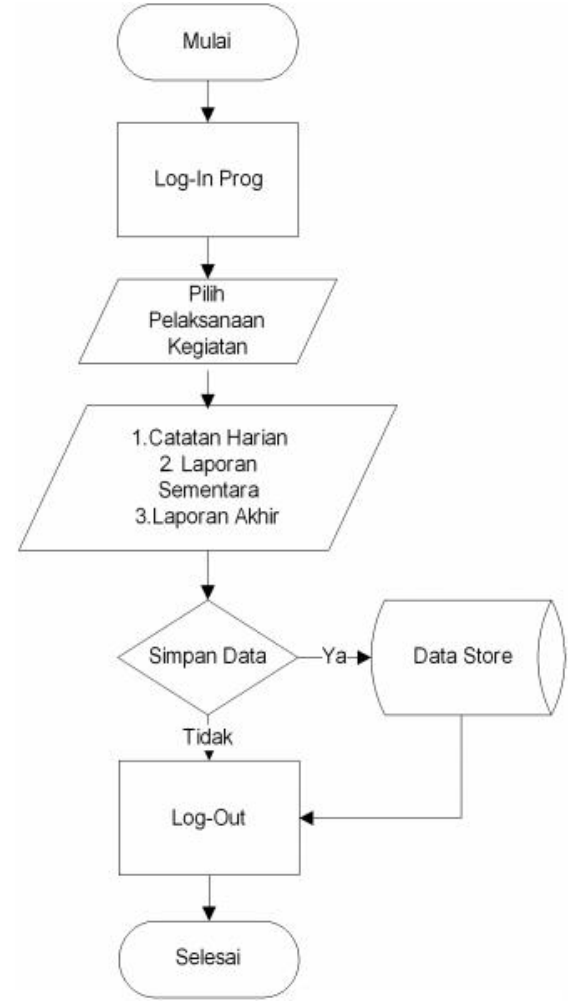

Gambar 2. FlowChart Pelaksanaan Kegiatan

Pada Gambar 2 Dosen memilih pelaksanaan kegiatan kemudian menginput data baik catatan harian, laporan harian, dan laporan akhir setelah itu dosen menyimpan data, jika dosen menyimpan data maka data akan tersimpan di database lalu keluar dari sistem, jika tidak maka dosen akan keluar dari sistem.

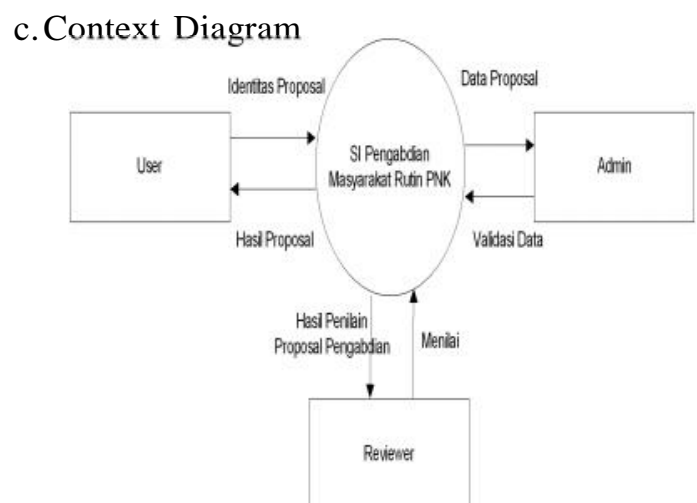

Gambar 3. Context Diagram SI Pengabdian Masyarakat Rutin PNK 
Dari Gambar 2 diatas dapat dilihat bahwa dalam SI Pengabdian Masyarakat Rutin PNK terdapat tiga entitas, tiga entitas tersebut yaitu: User, Admin, Reviewer.

1) User,

Merupakan pengguna Sistem Informasi Pengabdian Masyarakat Rutin PNK baik itu dalam hal pengusulan proposal maupun dalam melihat hasil laporan.

2) Admin,

Merupakan pemegang/penyimpan dan pengontrol data proposal pengabdian

3) Reviewer, merupakan penilai dalam menilai suatu proposal baik itu proposal pengabdian maupun proposal penelitian.

d.Data Flow Diagram (DFD)

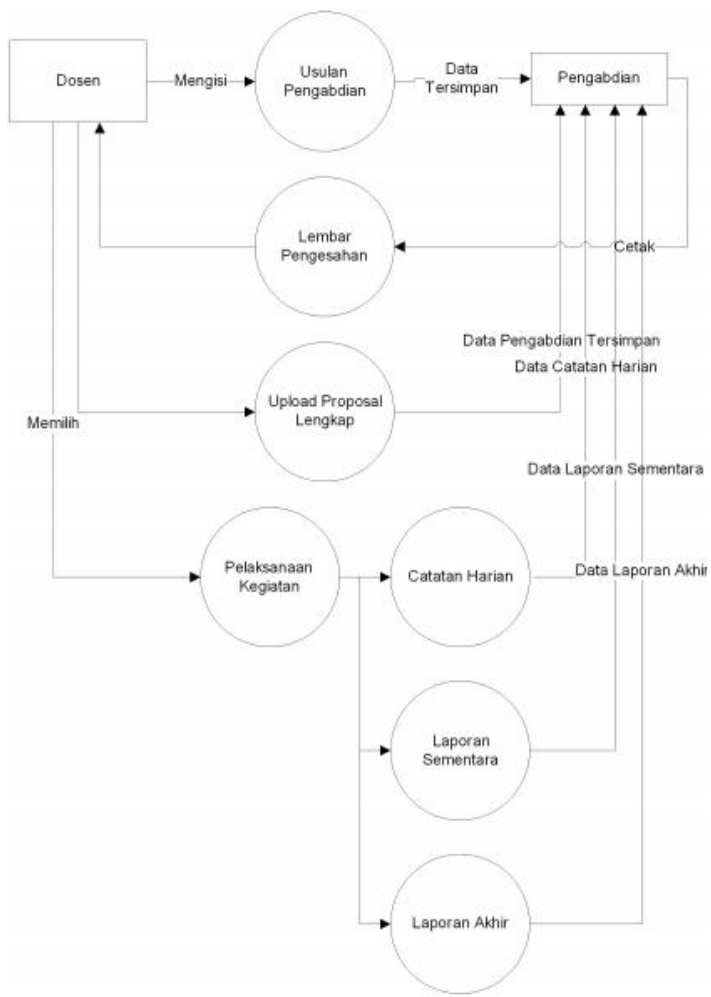

Gambar 4. DFD Level 1 Alur Sistem

Bagan di diatas menjelaskan urutan dari prosedur-prosedur yang ada di dalam alur sistem. Prosedur ini digunakan di Unit Penelitian dan Pengabdian Masyarakat (UPPM) Politeknik Negeri Kupang. Berikut adalah penjelasannya. Proses Rincian Usulan Baru Pengabdian Masyarakat Rutin Dosen mengusulkan usulan pengabdian kemudian data tersimpan didatabase setelah itu dosen mencetak lembar pengesahan, langkah selanjutnya dosen mengupload proposal lengkap pengabdian lengkap. Langkah berikutnya dosen memilih pelaksanaan kegiatan kemudian menginput data berupa catatan harian, laporan sementara, dan laporan akhir setelah itu data tersimpan didatabase pengabdian.

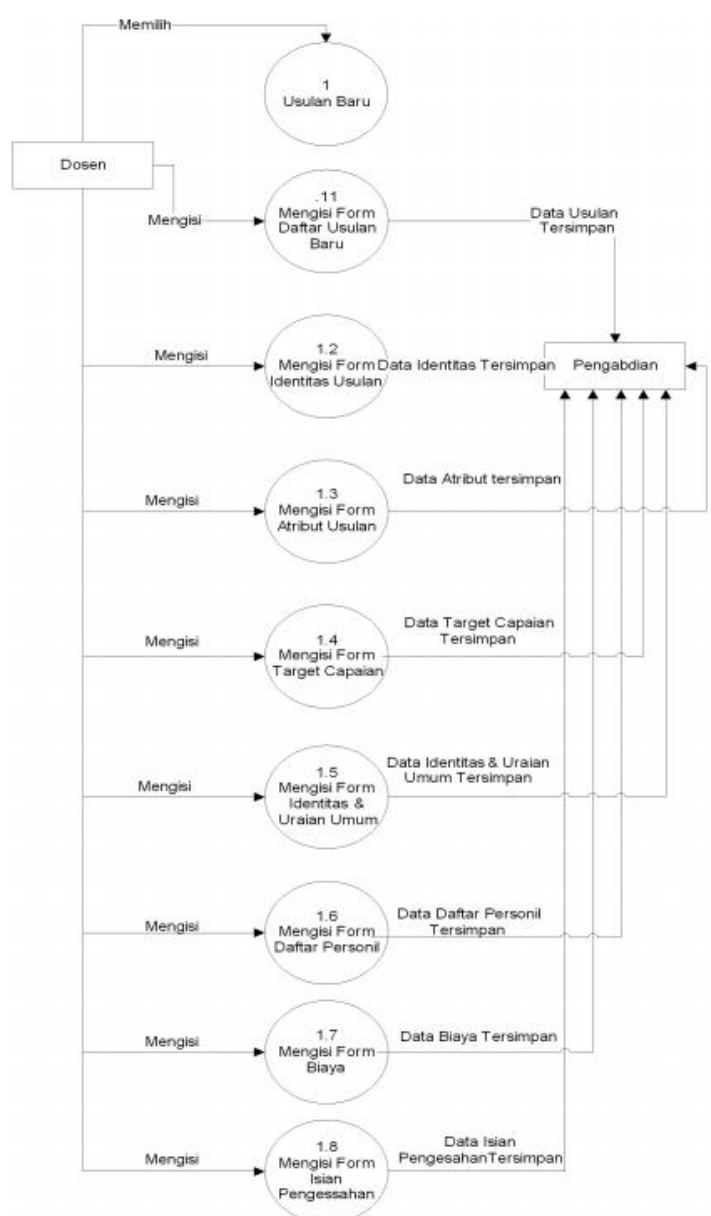

Gambar 5. Rincian Proses Usulan Pengabdian

Dari Gambar 5 diatas Dosen mengusulkan usulan baru pengabdian kemudian mengisi form daftar usulan baru, berupa identitas usulan, atribut usulan, target capaian, identitas dan uraian umum, daftar personil, biaya dan 
form isian pengesahan, kemudian data tersebut disimpan pada database pengabdian.

Proses Rincian Pelaksanaan Pengabdian Masyarakat Rutin

1) Pelaksanaan Kegiatan Catatan Harian.

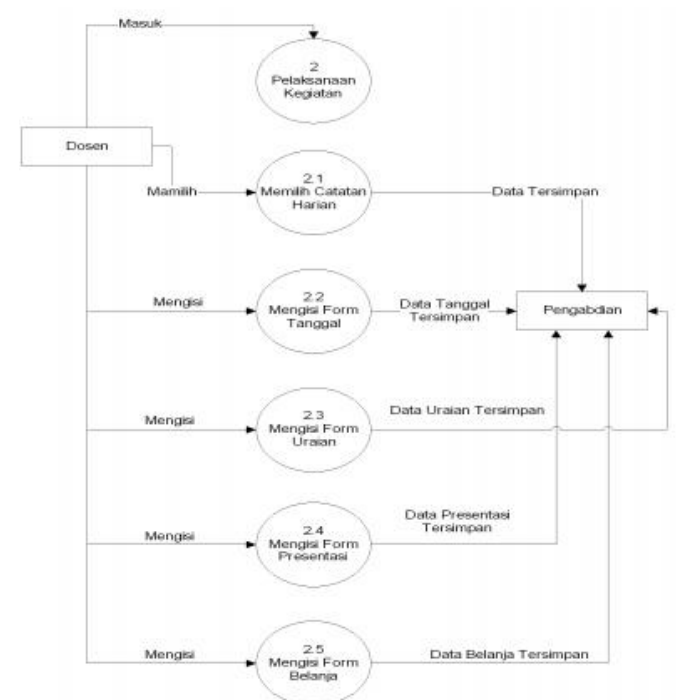

Gambar 6. Rincian Proses Catatan Harian

Dari Gambar 6 diatas User memilih Pelaksanaan kegiatan kemudian memilih catatan harian dan mengisi form catatan harian berupa form tanggal, uraian, presen-tasi, belanja, kemudian data tersebut disim-pan di database pengabdian.

2) Pelaksanaan Kegiatan Laporan Kemajuan.

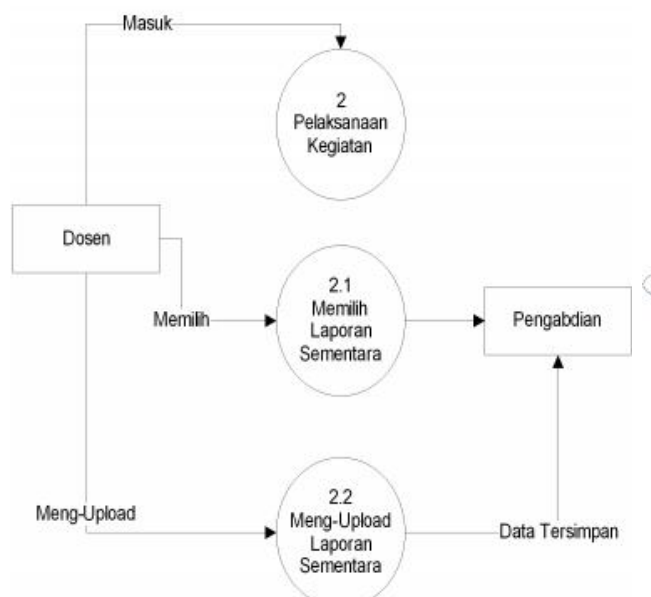

Gambar 7. Rincian Proses Laporan Sementara
Dari Gambar 7 diatas User memilih pelaksanaan kegiatan kemudian memilih laporan sementara dan meng-upload laporan sementara data tersebut tersimpan di database pengabdian.

3) Pelaksanaan Kegiatan Laporan Akhir.

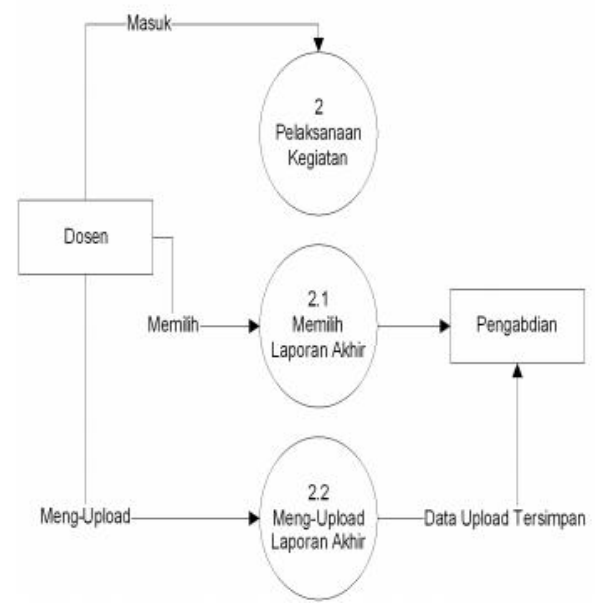

Gambar 8. Rincian Proses Laporan Akhir

Dari Gambar 8 diatas memilih pelaksanaan kegiatan kemudian memilih laporan akhir dan mengupload laporan akhir data tersimpan di database pengabdian.

e. Entity Relationship Disgram (ERD)

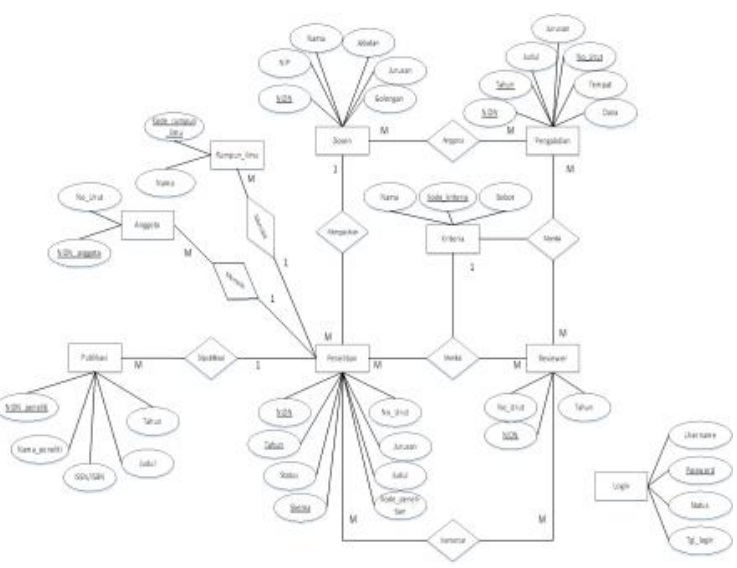

Gambar 9. ERD 


\section{\begin{tabular}{l|l|lll}
98 & Jurnal Ilmiah $F L A S H$ & Volume 2 & Nomor 2 & Desember 2016
\end{tabular}}

Proses relasi adalah sebagai berikut:

1) Hubungan antara tabel dosen dengan tabel pengabdian adalah Many To Many, yang artinya banyak dosen dapat mengajukan banyak proposal pengabdian.

2) Hubungan antara tabel pengabdian dengan tabel publikasi adalah One To Many, yang artinya satu pengabdian dapat dipublikasi beberapa jurnal.

3) Hubungan antara tabel pengabdian dengan tabel anggota adalah One To Many, yang artinya satu pengabdian dapat dimiliki beberapa anggota.

4) Hubungan antara tabel pengabdian dengan tabel reviewer adalah One To Many, yang artinya satu pengabdian dapat dinilai oleh beberapa reviewer.

5) Hubungan antara tabel reviewer dengan tabel kriteria adalah One To Many, artinya satu reviewer memiliki beberapa kriteria panilaian.

\section{f. Rancangan Tabel}

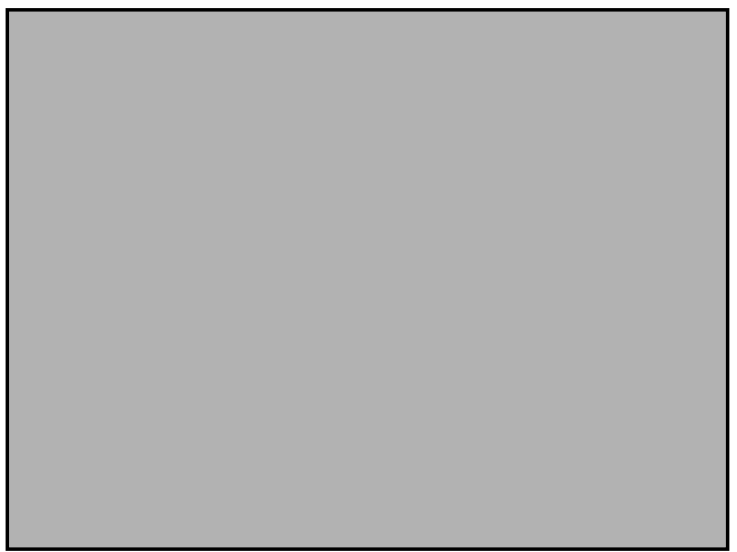

Gambar 10. Relasi Antar Tabel

\subsection{Implementasi Aplikasi}

Sistem Informasi Pengabdian Masyarakat Rutin PNK adalah aplikasi yang akan diimplementasikan untuk dapat membantu dalam proses pengelolahan data pengabdian masyarakat berupa pengusulan proposal. Berdasarkan pembuatan aplikasi, maka hasil yang penulis kerjakan dalam Sistem Informasi Pengabdian Masyarakat Rutin PNK adalah sebagai berikut:

\subsubsection{Log In sebagai Pengusul}

Log in sebagai pengusul merupakan tahap awal masuk kedalam sistem pengabdian masyarakat disini dosen akan masuk sebagai pengusul disini pengusul harus memasukan nidn dan nip.

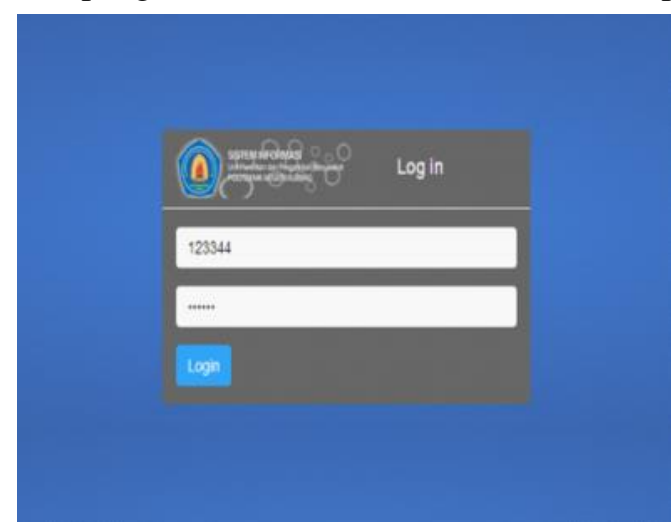

Gambar 11. Tampilan Login Sebagai Pengusul

\subsubsection{Tampilan Halaman Home}

Jika masuk sebagai pengusul maka setelah login akan masuk he halaman home

1. Tampilan halaman home

Halaman ini terdapat 3 menu utama yaitu home, penelitian, dan pengabdian,

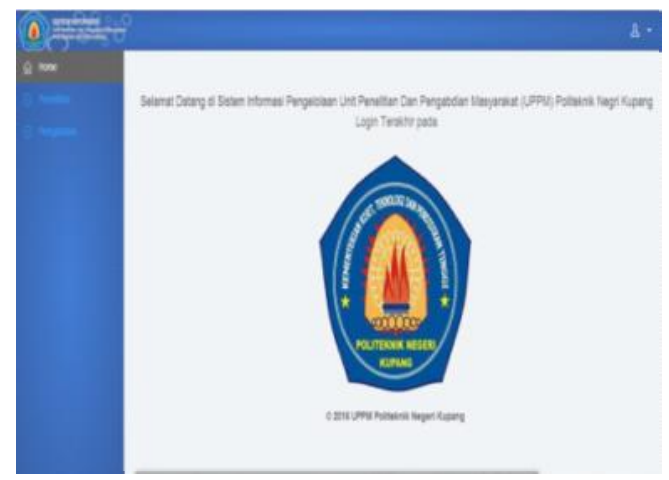

Gambar 12. Tampilan halaman home

2.Tampilan halaman Usulan Baru (Input Proposal Pengabdian Baru)

Setelah muncul halaman pengusul mengklik pengabdian maka akan muncul seperti pada gambar. 


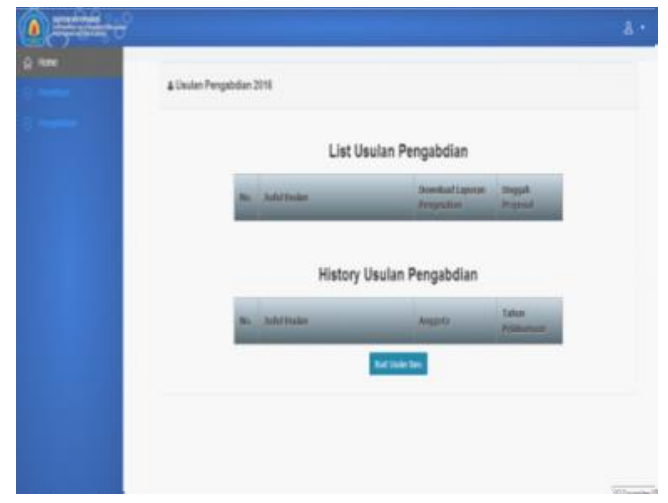

Gambar 13. Tampilan Tambah Usulan

\subsubsection{Tampilan Pengisian Form Usulan Baru}

Jika pengusul ingin mengusul usulan pengabdian baru maka pengusul harus mengklik tombol Buat Usulan Baru selanjutnya pengusul harus mengisi form inputan berupa form Identitas Usulan, Form Atribut Usulan, Form Target Capaian, Identitas dan Uraian Umum, Form Anggota, Form Biaya dan terakhir Form Pengesahan. Pengusul mengisi form atribut usulan. Berikut tampilan input tambah pengabdian.

1). Tambah Usulan

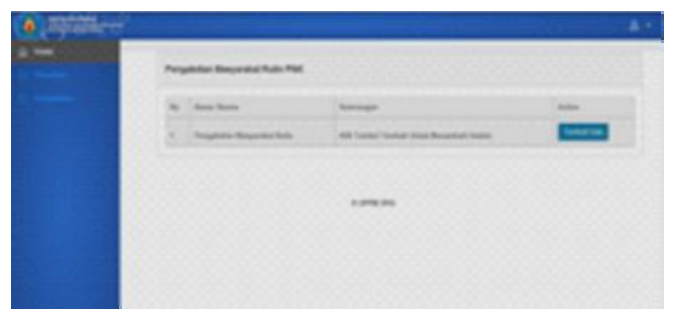

Gambar 14. Tampilan Tambah Usulan Baru

2). Identitas Usulan

Pengusul mengisi form identitas usulan. Berikut tampilan input identitas usulan pengabdian.

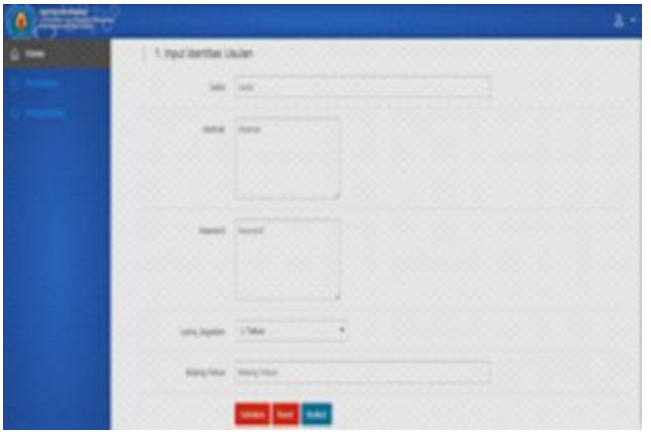

Gambar 15. Tampilan Tambah Usulan Baru

3). Atribut Usulan

Pengusul mengisi form atribut usulan. Berikut tampilan input atribut usulan pengabdian.

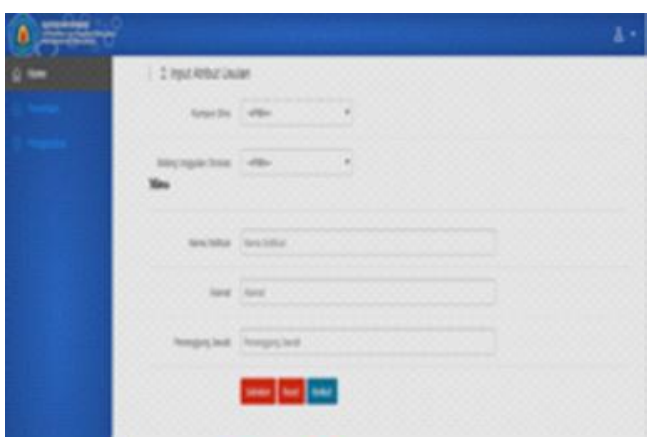

Gambar 16. Tampilan Atribut Usulan

4). Target Capaian

Pengusul mengisi target capaian. Berikut tampilan input target capaian pengabdian.

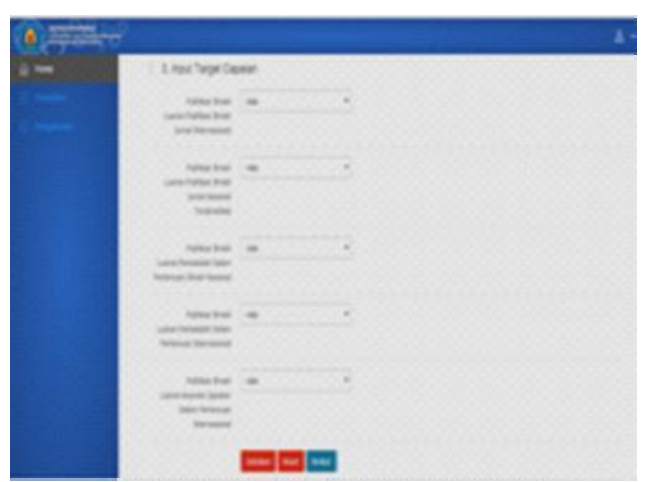

Gambar 17. Tampilan Target Capaian 


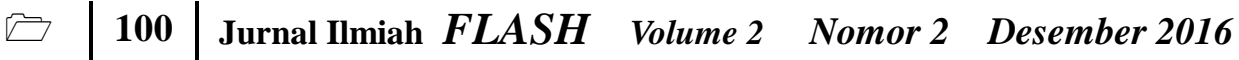

5). Identitas dan Uraian Umum

Pengusul mengisi form uraian umum. Berikut tampilan input Identitas dan Uraian Umum pengabdian.

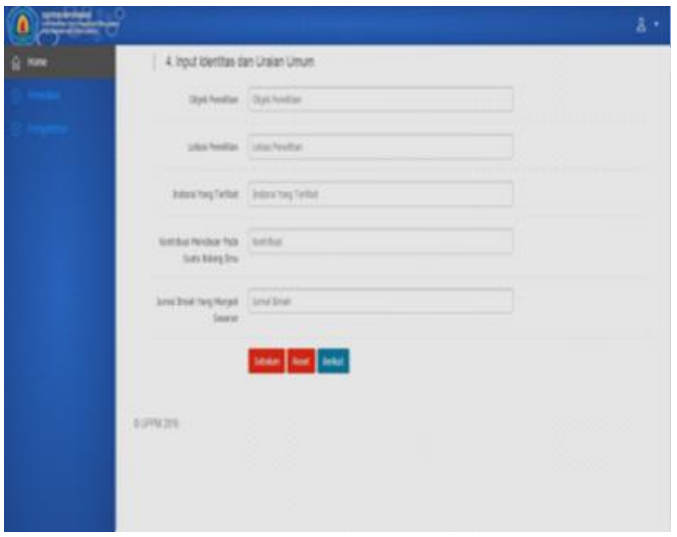

Gambar 18. Tampilan Identitas dan Uraian Umum

6). Anggota Pengabdian

Pengusul menginput anggota pengabdian. Berikut tampilan input anggota pengabdian.

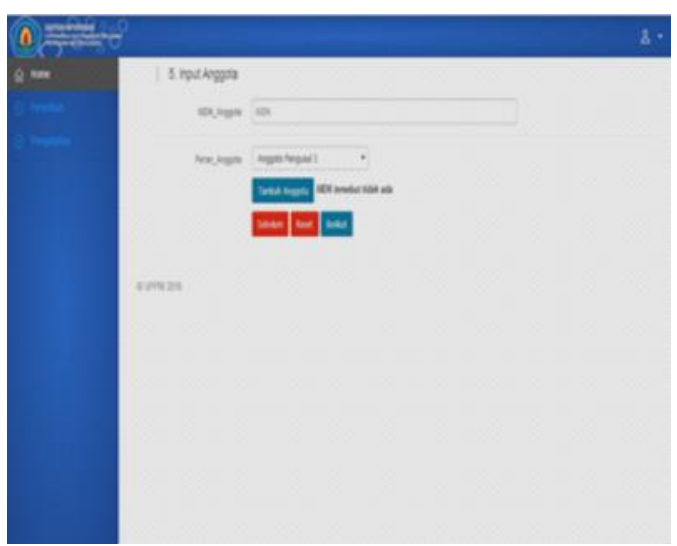

Gambar 19. Tampilan Anggota Pengabdian

7). Biaya

Pengusul menginput biaya. Berikut tampilan input biaya pengabdian.

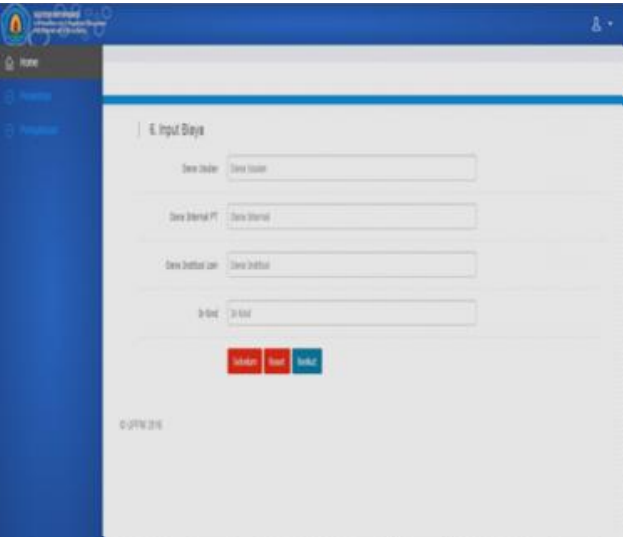

Gambar 20. Tampilan Biaya

8). Pengesahan

Pengusul mengisi form pengesahan. Berikut tampilan input pengesahan pengabdian.

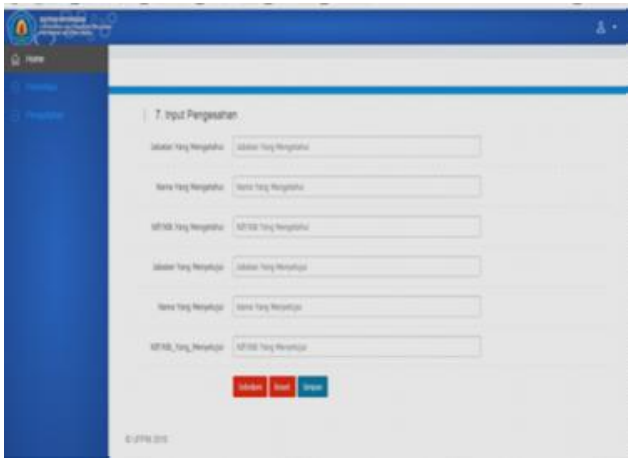

Gambar 21. Tampilan Pengesahan

9). Tampilan Halaman Setelah Data Pengabdian di Input. Berikut tampilan halaman home setelah data pengabdian diinput.

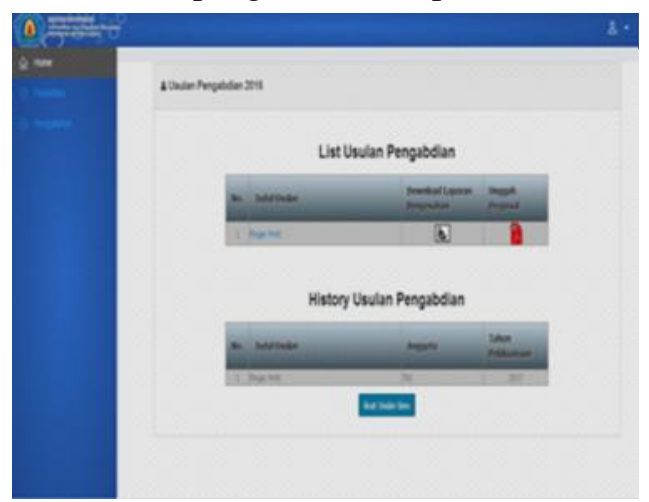

Gambar 22. Tampilan Halaman Home Sete-lah Data Pengabdian di Input 


\subsubsection{Pengesahan Proposal Pengabdian}

Jika kita telah menginput data maka langkah berikutnya klik gambar printer untu mencetak lembar pengesahan. Berikut tampilan halaman pengesahan pengabdian.

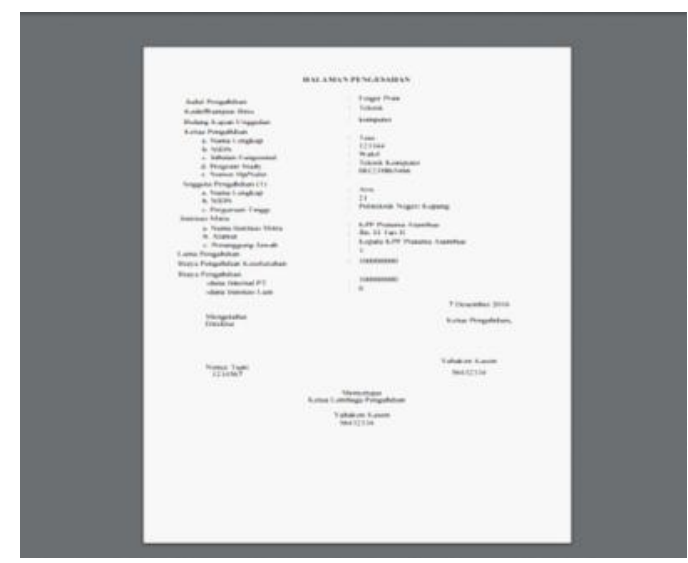

Gambar 23. Tampilan Membuat Database

\subsubsection{Edit Proposal Pengabdian}

Jika data yang diinput ingin dirubah maka klik judul proposal yang digarisbawahi dan yang ada dalam tabel. Berikut tampilan keseluruhan edit data usulan baru.

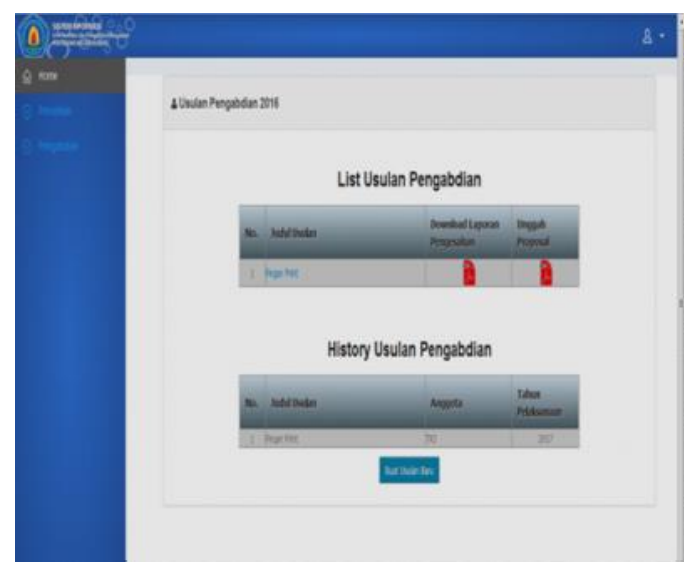

Gambar 24. Tampilan Membuat Database

1). Edit Identitas

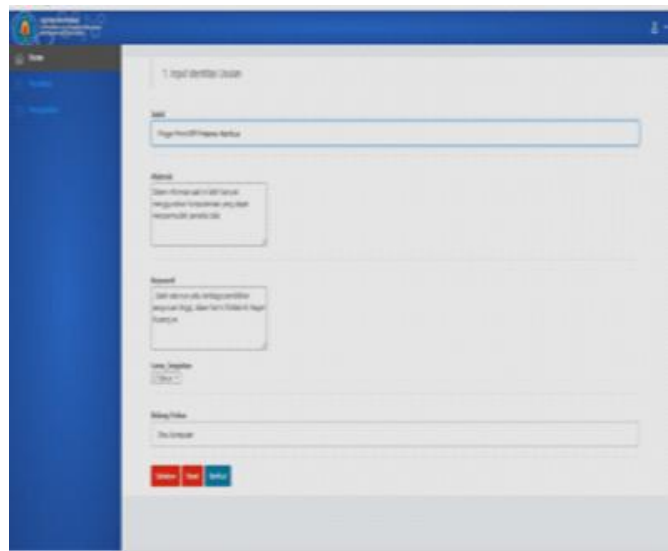

Gambar 25. Tampilan Edit Identitas

2). Edit Atribut

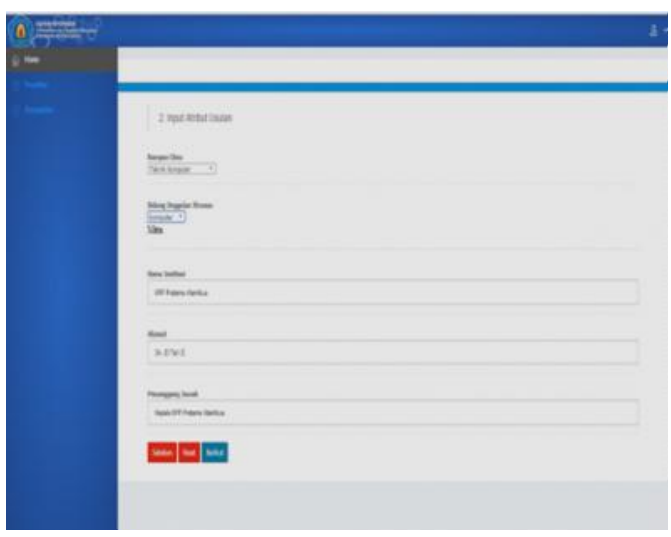

Gambar 26. Tampilan edit Atribut

3). Edit Target Capaian

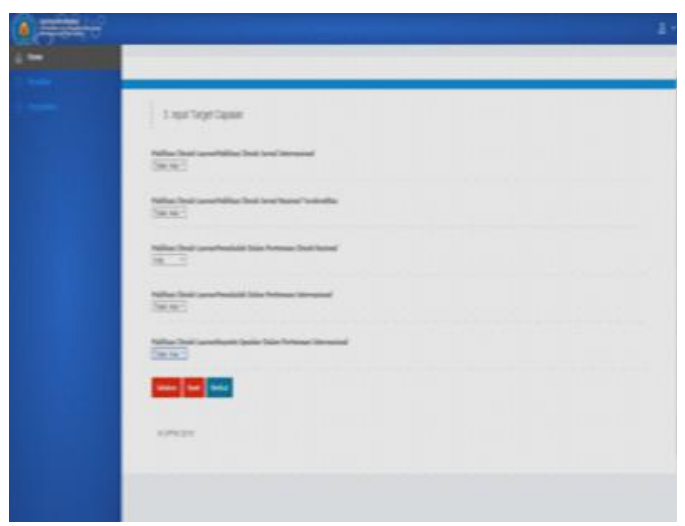

Gambar 27. Tampilan Edit Target Capaian

4). Edit Identitas dan Uraian Umum 


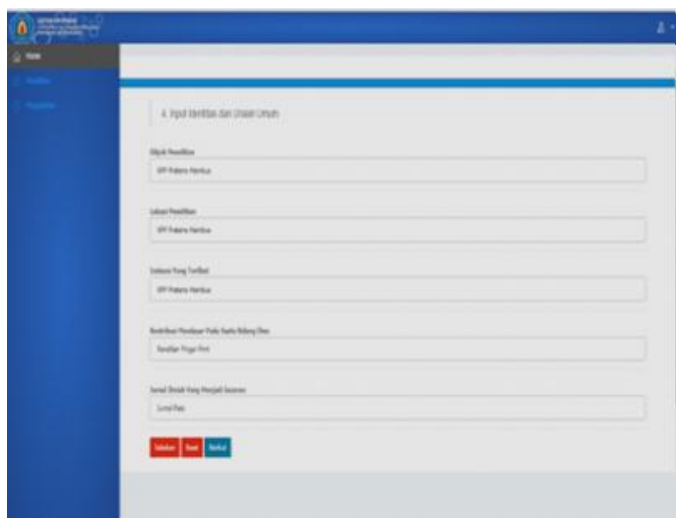

Gambar 28. Tampilan Edit Identitas dan Uraian Umum

\section{5). Edit Anggota}

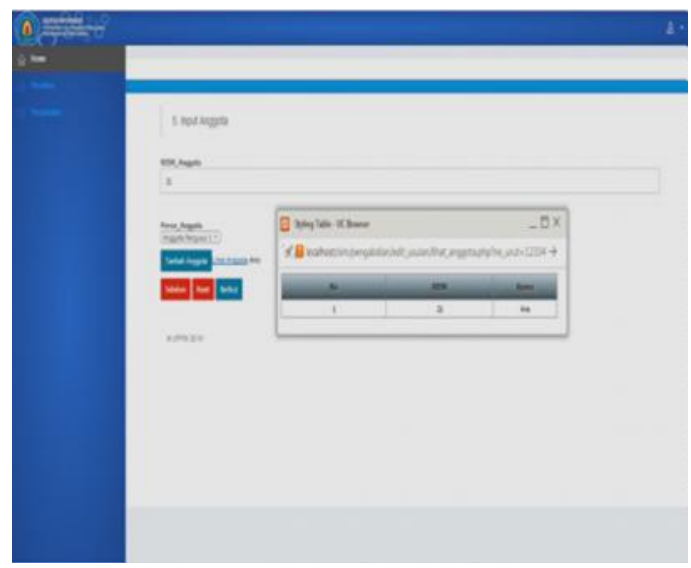

Gambar 29. Tampilan Edit Anggota

6). Edit Biaya

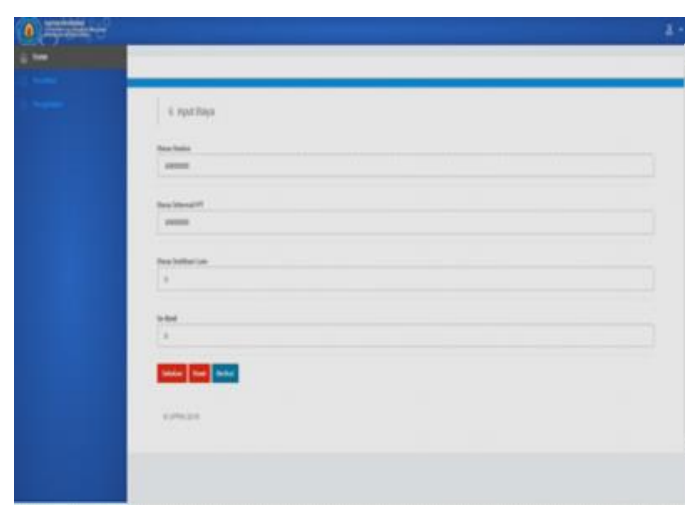

Gambar 30. Tampilan Edit Biaya

7). Edit Pengesahan

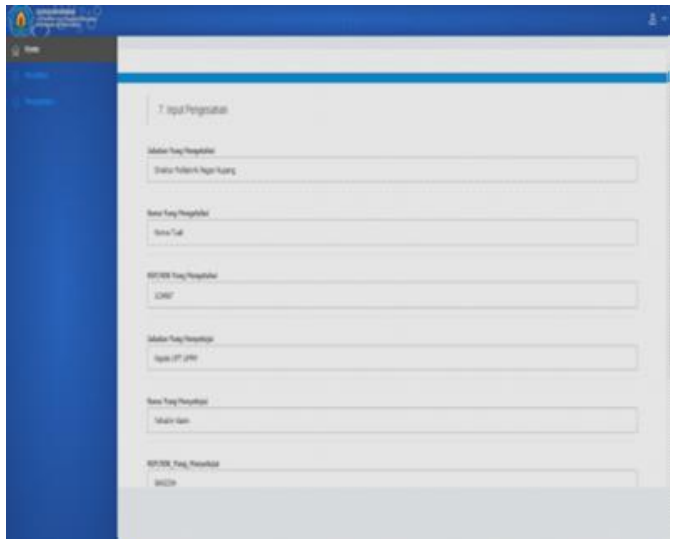

Gambar 31. Edit Pengesahan

7). Edit Pengesahan

\subsubsection{Unggah Proposal Pengabdian}

Setelah data telah diinput maka selanjutnya pengusul dapat mengunggah proposal pengabdian dengan cara pada tampilan halaman homen didalam tabel terdapat kolom unggah proposal klik gambar pada kolom tersebut. Berikut tampilan unggah proposal.

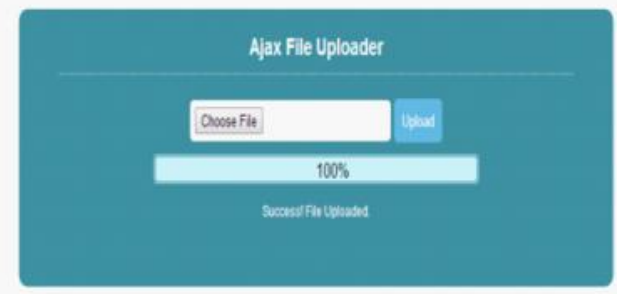

Gambar 32. Edit Pengesahan

\subsubsection{Konfirmasi Anggota Pengabdian}

Anggota yang telah diinput oleh pengusul kemudian akan dikonfirmasi sendiri oleh anggota. Caranya dengan masuk sebagai anggota pengabdian kemudian mengkonfirmasi. Berikut tampilan konfirmasi anggota:

1)Masuk Sebagai Anggota Pengabdian 


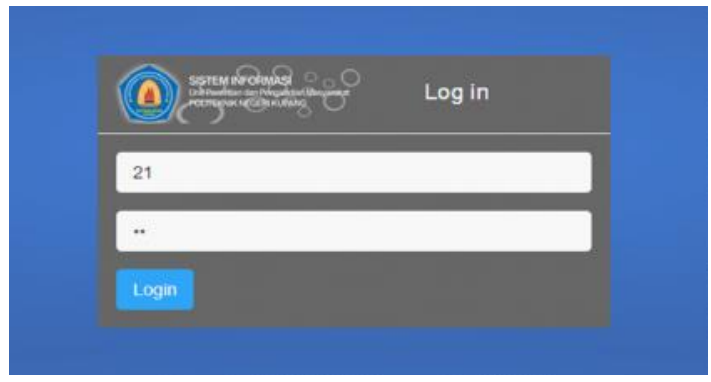

Gambar 33. Tampilan Login Sebagai Anggota Pengabdian

2)Masuk halaman home pengabdian kemudian klik konfirmasi anggota maka akan muncul seperti pada gambar.

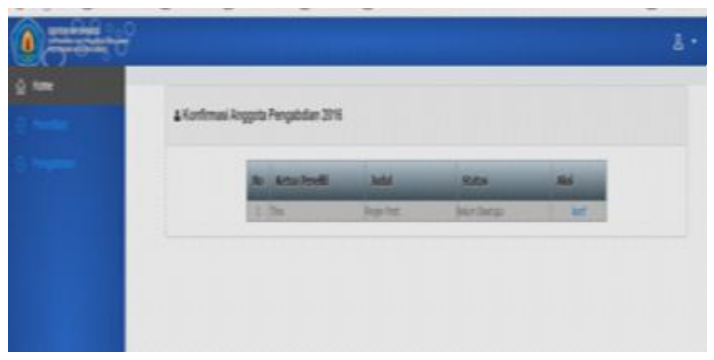

Gambar 34 Tampilan Konfirmasi Anggota

\subsubsection{Catatan Harian}

1)Masuk halaman home pengabdian kemudian klik catatan harian maka akan muncul seperti pada gambar.

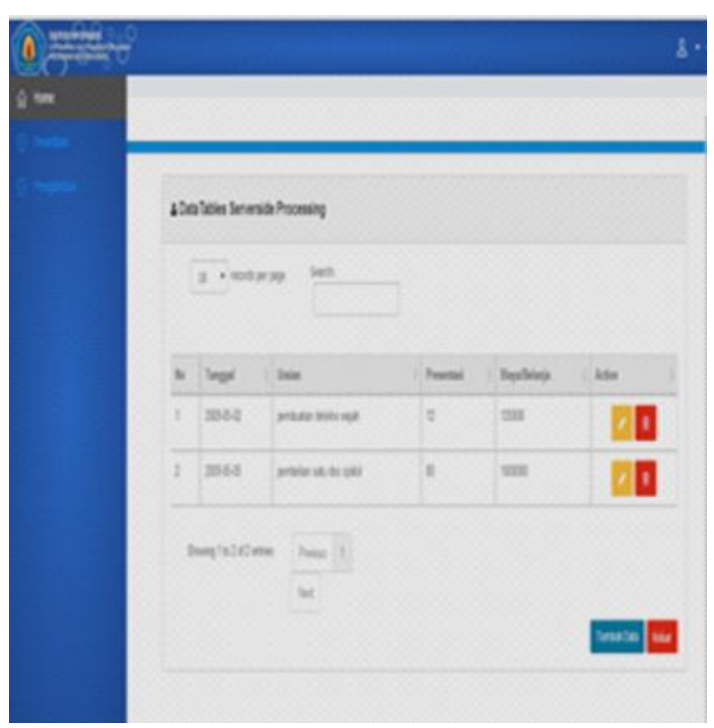

Gambar 35. Tampilan Catatan Harian
2)Langkah berikutnya setelah muncul tampilan tabel catatan harian klik tambah data kemudian akan muncul form isian seperti pada gambar. Langkah selanjutnya setelah mengisi form catatan harian kemudian klik tombol simpan.

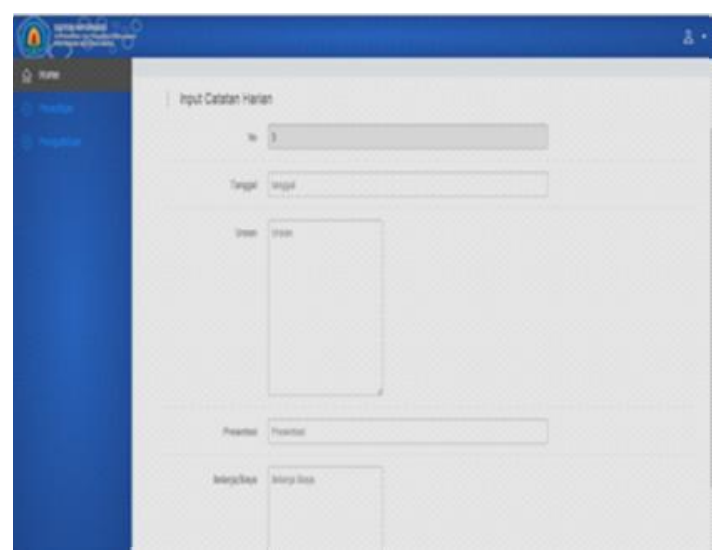

Gambar 36. Tampilan input Catatan Harian

\subsubsection{Laporan Kemajuan}

Masuk ke halaman home pengabdian kemudian klik laporan kemajuan maka akan muncul seperti pada gambar. Didalam gambar tersebut pengupload bisa mengupload laporan kemajuan dan juga pengusul dapat melihat lembar pengesahan laporan kemajuan.

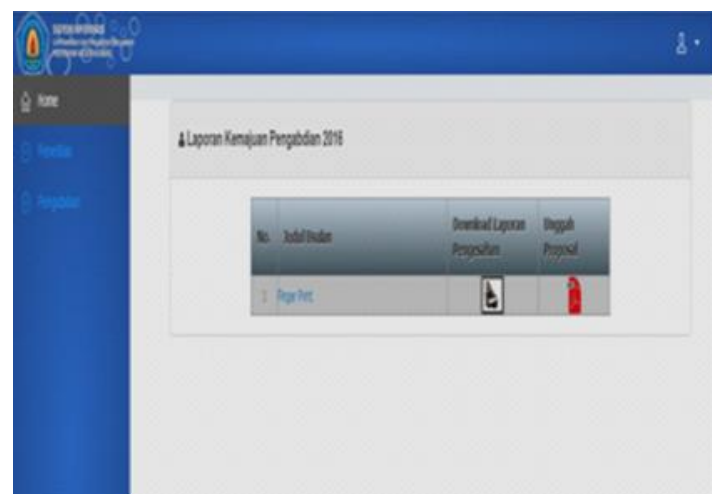

Gambar 37. Tampilan Laporan Kemajuan

\subsubsection{Laporan Akhir Pengabdian}

Sama dengan laporan kemajuan, pada laporan akhir pengupload masuk ke halaman home pengabdian kemudian klik laporan 


\section{이}

kemajuan maka akan muncul seperti pada gambar. Didalam gambar tersebut pengupload bisa mengupload laporan kemajuan dan juga pengusul dapat melihat lembar pengesahan laporan kemajuan.

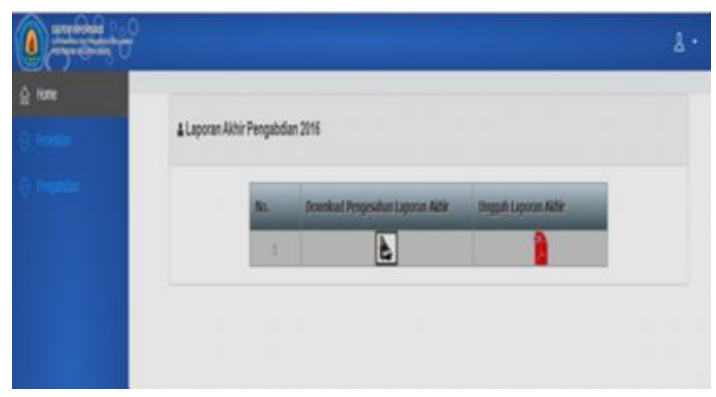

Gambar 38. Tampilan Laporan Akhir

\subsubsection{Kuitansi}

Jika pengusul ingin mengisi kuitansi maka pengusul masuk ke halaman home pengabdian kemudian klik kuitansi maka akan muncul seperti pada gambar.

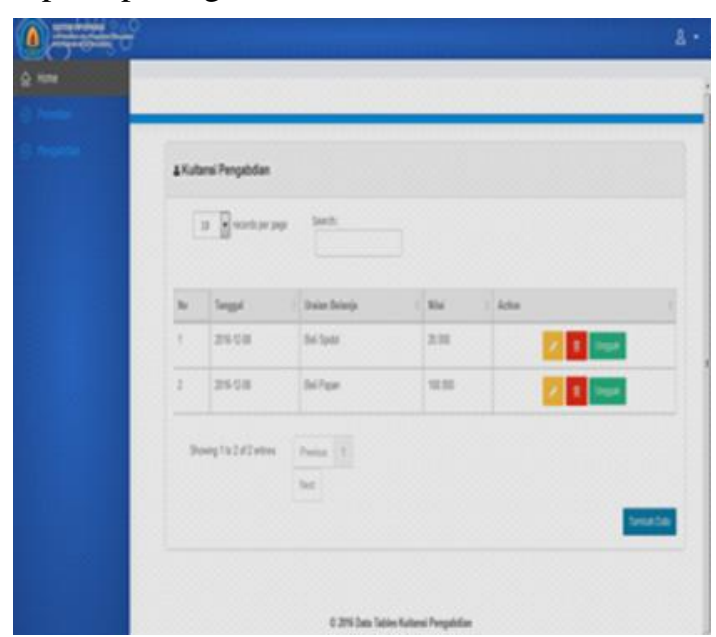

Gambar 39. Tampilan Kuitansi

\section{KESIMPULAN DAN SARAN}

\subsection{Kesimpulan}

Berdasarkan percobaan-percobaan yang telah dilakukan, dapat diambil kesimpulan Sistem ini hanya melakukan penginputan proposal pengabdian secara otomatis, pengeditan proposal pengabdian dan konfirmasi anggota pengabdian.

\subsection{Saran}

Berdasarkan penelitian dan analisis hasil, terdapat beberapa saran untuk perbaikan sistem selanjutnya. Saran-saran tersebut diantaranya adalah:

a. Untuk membuat sistem yang baik dan efektif, sebaiknya dikerjakan dalam tim sehingga dapat berbagi tugas, ada yang bertugas untuk mendesain, ada yang bertugas sebagai programmer dan pembagian tugas lainnya, sehingga sistem dapat diselesaikan dengan cepat dan efektif.

b.Dalam pengembangan aplikasi ini masih menggunakan Bahasa Indonesia, harapan kedepannya bahwa aplikasi ini dapat dikembangkan dan dapat digunakan secara universal dengan bahasa universal.

c. Semoga kedepannya aplikasi ini dapat dikembangkan menjadi lebih dinamis dan lebih menarik.

\section{DAFTAR PUSTAKA:}

Anonim.http://simlibtmas.dikti.go.id. Diakses tanggal 20Agustus 2016.

Anonim. http://simlibtmas.ritekdikti.go.id. Diakses tanggal 20Agustus 2016.

Anonim. http://lppm.ugm.ac.id. Diakses tanggal 20Agustus 2016.

Anonim. http://lppm.upi.edu. Diakses tanggal 20Agustus 2016.

Anonim. http://www.lppm.itb.ac.id. Diakses tanggal 20Agustus 2016.

Anonim. http://www. dp2m.umm.ac.id. Diakses tanggal 20Agustus 2016. 
Eniyati, Sri \& Santi, Rina Candra Noor. 2010. Perancangan Sistem Pendukung Keputusan Penilaian Prestasi Dosen Berdasarkan Penelitian dan Pengabdian Masyarakat. Jurnal Teknologi Informasi DINAMIK, Volume 25, Nomor 2. http://www. unisbank. ac.id/ojs/index.php/fti1/article/download/ 121/116. Diakses tanggal 20Agustus 2016.

Hamzah. 2016. Sistem Pengolahan Data Kegiatan Penelitian dan Pengabdian Kepada Masyarakat di Universitas Respati Yogyakarta. Scientific Journal of Informatics, Volume 3, Nomor 1. http:// journal.unnes.ac.id/nju/index.php/sji. Diakses tanggal 20 Agustus 2016.
Sukadarmika, Gede, dkk. 2014. Sistem Informasi Pengelolaan Proposal Penelitian Dan Pengabdian Masyarakat Secara OnLine. Jurnal Teknologi Elektro, Volume 13, Nomor 2. http://ojs.unud.ac.id/index.php/ JTE/article/view/18859. Diakses tanggal 20Agustus 2016. 